\title{
THE PROCESS OF HISPANIZATION IN EARLY NEW SPAIN TRANSFORMATION OF COLLECTIVE IDENTITIES DURING AND AFTER THE CONQUEST OF MEXICO
}

POR

FELIX HINZ

Universität Kassel

This article examines the methods and results of cultural change during the conquest of Mexico and in the early New Spain. It is the attempt to systemize the mechanisms of Christianisation and «Hispanization» - which can be understood as a reciprocal process of the transformation of collective identities. The fact that an indigenous clergy was not created was generally misunderstood as the Nahuas' incapability to meet to the requirements of Spanish morality and civilization («policía»). This had effects on the political as well as on the architectural or historiagraphical spheres. But also the Spaniards and Europeans in general had to question themselves after their contact with the Nahua culture. To be "Spanish" before and after the conquest as well as to be «Spanish» in Spain and in Las Indias did not mean the same.

KeY words: cultural change, New Spain, Christianisation, Hispanization.

Does the conquest of Mexico really represent a radical break with the culture of the Nahua Indians - or does this interpretation represent today's ignorance in view of those former changes?

By now, the bold notion of «the Spaniards» who have completely destroyed «the Indian culture» with a series of military victories has already been significantly investigated by researchers. Studies, especially those by José Luis Martínez ${ }^{1}$ and Juan Miralles Ostos ${ }^{2}$, give a good and current overview about the conquest of Mexico from the point of view of the conquerors.

1 Martínez, 1992.

2 Miralles Ostos, 2001. 
But the aforementioned authors have only been slightly familiar with the Nahua Indian culture and thus have not succeeded - just like their predecessors - in trying to present the Indian perspective.

More recent versions of Indian sources which have been drafted under Spanish rule have shown that the conquest of Mexico can primarily be understood as a war between different Nahua tribes, a war that Hernán Cortés has cleverly been able to engineer and control.

Especially research conducted by Charles Gibson ${ }^{3}$, Serge Gruzinski ${ }^{4}$, James Lockhart ${ }^{5}$, and Andrea Martínez Baracs ${ }^{6}$ have shown that these Indian cultures have in no way been completely, but rather only partially suppressed, and that a lot of cultures managed to outlive the conquest. These researchers focus on how the life of the Nahua tribes had been affected by the conquest, which Spanish elements they have adopted, which is to say, their approach is mainly descriptive in character. In those studies, «the Spaniards» are represented as an almost undifferentiated group of people, as initiators of a subjugation program which is not clearly defined. Until today it has not comprehensively been clarified what this «program» actually involves.

The questions are: Which parts should have been affected by this particular program and which not? How did these changes come about? Who were the initiators, who were the target group? Which plans and ideas did those people have in mind and what was the reaction of the target groups? How do we have to interpret the results? In short: Until now there is a lack of research which deals with the changes and at the same time considers the before and after. There is a lack of research which takes today's knowledge of the Nahua Indian culture into consideration also in view of the history of the conquest, a lack of research which shows the reciprocal nature of the changes of collective identities and systemizes this process by means of adequate theories and terminology. This gap shall be closed by the research «Hispanisierung» in Neu-Spanien 1519- 1568. Transformation kollektiver Identitäten von Mexica, Tlaxkalteken und Spaniern (= «Hispanization» in New Spain 1519-1568. Transformation of the collective identities of Mexica, Tlaxcaltecs and Spaniards), of which the following article provides a synopsis with some striking examples.

Surely Indian cultures have been transformed. But they have preserved their Indian ways, sometimes even until today. In the $21^{\text {th }}$ century this does not

\footnotetext{
3 GiBSON, 1952; 1964.

4 GRUZINSKI, 1988.

5 LOCKHART, 1992.

6 Martìnez BARACS, 1998.
} 
surprise anybody, but for $16^{\text {th }}$ century Europeans this was an unexpected experience. It was because of this unexpected turn of events that the Spaniards also questioned their own collective identity. Alongside their old medieval and universal world, a new world had emerged, which did not follow the traditional European concepts. This is why the question that has to be dealt with is not solely a question of local or ethnohistorical change, but also of historical ideology perspectives. The fact that the transformation process of the Nahua Indian cultures did not provide a tabula rasa for implanting the European ways but for a different and new cultural reality, requires an exemplary specification, although the actual mechanisms of the transformation should not be neglected.

For this reason one must focus, with regard to the parties involved, on an approach which is detailed enough but also generally applicable. In order to present in detail the target group: the Indian Nahuas - one should not regarded them as a homogeneous group. Because the Hispanization has been taken up differently by the Nahua tribes, the research focuses on two Indian groups in Central-Mexico, who on the one hand shared enough common views that a comparison between the two is sensible, but on the other hand were also very different from each other.

Generally speaking, one is inclined to regard the different Nahua tribes the Tlaxcaltecs and the Mexica (Aztecs) - as «winners» and «losers» of the conquest of Mexico. But different developments within these groups need to be taken into account as well as the fundamental difference between the theoretical approach (as recorded in the historical sources) and what actually happened. On the other hand, one needs to take into consideration that the Spaniards themselves were a heterogeneous group and that sensible subcategories within these groups need to be formed. In addition, one has to critically question what it meant and involved in those days to be Spanish in a part of the world where nobody else was Spanish, and what being Spanish meant before and after the conquest. Apart from that, one should keep in mind that the missionaries who indeed had the most important influence on the transformation of the collective identities of the Mexica and Tlaxcaltecs, can not be regarded as prototypical Spanish in any way. For this reason the basis of the research is at least threefold: The «Spaniards» (on the one hand the Crown, on the other, the conquerors or encomenderos), the «Church» (f. e. the pope, the Franciscan friars and other orders), and the Indians (Mexica and Tlaxcaltecs).

The period that is looked at in this study is from 1519-1568; a period of time in which the decisions for a new strategic direction for the ongoing historical development of Mexico and Las Indias in general were taken. 1568, the year of the Junta Magna, marks the end of the experimental phase with regard 
to the Hispanization, which is why this year is chosen to be a sensible limit of the research.

\section{General Results of Hispanization in Early New Spain}

On the basis of numerous examples of the transformation of collective identities, it becomes apparent that those can only be accomplished through the process of inculturation. Even though the organisation of collective memories in the form of «story tellers» - $\mathrm{f}$. e. heathen priests and writers - as well as precortesian sacral places of worship were destroyed, those aspects survived which have been passed on orally. That is especially true if the native tongues were still used, because language determines thought, thus a special (Indian) language determines a very specific way of thinking. Taken this into account, it is obvious that collective memories never pose a tabula rasa in reality - no matter what kind of «shock» a people have received. A total loss of the collective memory is only a theoretical assumption.

If a change of identity is sought to be brought about forcefully, the result is only to disturb the communication at best. But it is as impossible to read individual thought as collective thought. Traditional identities are being maintained in secrecy. This can only be prohibited in an absolutely transparent society, just like the Franciscan friars with their Colegio de Santa Cruz de Tlatelolco had in mind (as we will see below). There was just surface area, no privacy, nothing secretly hidden - no full-fledged identity of the Indian pupils. But the Spaniards lacked the capacity and common vision to put a surveillance system like this into action in all parts of New Spain. A reciprocal cultural mix was the consequence.

Interculturation and cultural mix only function on a voluntary basis. If these processes take place after a conquest, it is beneficial if reciprocal acceptance is enhanced through the conquerors' adopting of rituals of the defeated people. In this way it legitimizes their superiority. This can be achieved through dynastical alliances, just like Cortés or the conquerors have systematically tried to do it, or also through sacral legitimization. However, the Spanish conquerors and settlers did not consider the latter option. Their intolerant monotheism rather posed one of the major obstacles for the process of reciprocal change of identities or even a complete mergence of Indian and Spanish groups.

Another feature of the transformation of collective identities through forceful subjugation of a people that has been classified as «worthy of being civilised», was what the Fosterian concept of «culture of conquest» included. It is 
artificially, simplified, idealized ${ }^{7}$ - and ideologically motivated as I would like to add. This concept, a «culture of conquest» can also be rendered into a «religion of conquest», in which all potentially problematic and ambiguous aspects were either simplified or even kept as a secret. The culture of conquest and religion deliberately rules out to equip the defeated people with knowledge that could question the rule of the «civilised». In this particular case: weapons and warfare, dissenting opinions to the Roman Catholic Church as well as detailed knowledge of the Holy Bible and theology. In other words: A total Hizpanization would have meant that Indians could have been enabled and allowed to ride horses and fight with guns, or to dispute with Spanish priests about what is Christian. No need to say that there would have been a lot of possibilities to claim rights for self-determination and ask inconvenient questions about the Bible, the Church, or even about the legitimacy of the conquest and Spanish domination in general.

This is why the entire Hispanization was not really supported by any of the Spanish-Christian groups in New Spain. Although the claim was to enrich the other with achievements of their civilisation, and in this way open ways of legitimately dominating and exploiting the other, this aim, the mission of Christianisation and Hispanization, was never really designed to be totally achieved because then, the Spanish rule would have been ideologically superfluous.

\section{Some CONCRETE Results of the Hispanization In New Spain}

\subsection{Transformation of collective identities at the Spaniards}

The collective identity of Spain, which in 1519 was still in the process of being formed out of Castile, Aragon and recently conquered territories around Granada, and which at that time had a «foreign» king (Charles V), who during the first years could hardly speak Spanish, was positively stimulated by dealing with transatlantic cultures and especially by the conquest of Mexico. The very fact that this process just started makes it difficult to talk about «Hispanization» at this early stage. Add to this, there was no consensus among the Spanish groups and decisive individuals as to how and if a Hispanization should be carried out at all. The only thing they all agreed on was the fact that the heathens needed to be converted to Christianity.

7 Foster, 1960: 11. 
The confrontation with the other did not only lead to the accentuation of the self but concerning the Spaniards also to its jeopardizing. This becomes obvious when looking at Bartolomé de Las Casas' OP challenging and accusing writings. They were regarded as so distracting and painful that the Spaniards rejected his historical account as a Leyenda Negra, the «black legend». Las Casas had realized that the values that the chronicler López de Gómara and his humanist followers praised in order to glorify the Spanish nation only served the conquerors and encomenderos as an ideology. Moreover, through this demeanour they ran the risk of diminishing their Christian identity: «They [i. e. the conquerors] absolutely disregarded all respect for God and the king and forgot who they originally were $\rangle^{8}$. Las Casas unmasked the self-portrait of the conquerors as a sham who saw themselves as loyal, «romantic» knights accomplishing a divine mission. Cortés is even quoted by Las Casas with the cynic confession: «Begad, I went there like a noble corsair! $\rangle^{9}$ — and did according to the Dominican friar not even notice that this admission of guilt was contradictory to his Christian beliefs. In the following centuries, this contradiction formed the basis for the development of the Spanish identity as well as those of other European colonial powers.

The second legacy of this critical approach of the Spaniards concerning their own identity can be regarded as a big step towards universal human rights. According to Las Casas, any culture is the barbarian of the other ${ }^{10}$. Francisco de Vitoria OP dared to go even further: He questioned more or less indirectly the universal claim of the emperor as well as even the one of the pope. Thus, the medieval European world got smaller through the discovery of the New World and the conquest of Mexico: The world was neither undisputedly universal, nor were their values automatically universally valid. The Old World got a new rival, which had just as little knowledge of the redemption of Christ as the Holy Bible of its very existence. This ideological break was so unacceptable in the eyes of most Spaniards that it had to be done away with.

Thus, no European was against the conversion of the Indians to Christianity but there was a conflict among them as to how «civilization» was in line with the Spanish way of life and culture. For each group the Hispanization only served as a means, not as an end, and the Crown moreover became trapped in a contradiction, resulting in its typically inconsistent colonial poli-

8 LAs CASAS, Brevísima relación, 1992, vol. 10: 48.

9 Las Casas, Historia, tomo III, cap. CXIV, 1994, vol. 5: 2258.

10 Las Casas, Apologética, cap. («Sobre qué cosa es ser bárbaro») CCLXVII, epíl. [8], 1992, vol. 8: $1590 f$. 
tics. On one hand, Charles V was honestly determined to provide the Indians with better living conditions, and this included also an Hispanization, on the other, he needed an enormous amount of money for the imperial policy of the Habsburgs on the courts and battlefields of Europe - which again resulted in the reckless exploitation of the New World. The remaining Spanish groups that were relevant for New Spain were all rather against Hispanization anyhow and they supported the segregation of república de indios and república de españoles on the grounds of better control over the subjugated people.

However, as a justification of the allotment of encomiendas by Cortés and the king to the conquerors often was stated the Christianisation of Indians. But actually he of all encomenderos was accused several times of letting «his» Indians exercise their traditional religion ${ }^{11}$. The arguments for the encomien$d a$-system were not new: In settlements it should be easier to Christianise the indigenous if they lived scattered over the country. The missionaries had had this experience already before in Santo Domingo ${ }^{12}$. As a preparation for the systematic mission Cortés ordered therefore that the encomenderos had to start with the destruction of heathen objects of worship ${ }^{13}$, but this had little influence on the Tlaxcaltecs who did not fall under the regulations of encomienda. And the opinion that encomienda functioned as an instrument that promoted Hispanization in any way is mislead by encomienda-rules which had never gained practical effects. Already in 1964 Charles Gibson in drastic words pointed out:

Encomenderos used their Indians in all forms of manual labor, in buildings, farming, and mining, and for the supply of whatever the country yielded. They overtaxed and overworked them. They jailed them, killed them, beat them, and set dogs on them. They seized their goods, destroyed their agriculture, and took their women. They used them as beasts of burden. They took tribute from them and sold it back under compulsion at exorbitant profits. Coercion and ill-treatment were the daily practices of their overseers, calpixque, and labor bosses. The first encomenderos, without known exception, understood Spanish authority as a provision for unlimited personal opportunism ${ }^{14}$.

Although the conquerors and encomenderos always had pretended to devote themselves to the protection and Christianisation of the indigenous peo-

11 Cargos que resultan contra H. Cortés, 08.05.1529, Documentos cortesianos, 1992, vol. 2: 118 .

12 Los Padres Gerónimos al emperador Carlos V, 18.01.1518, Colección de documentos inéditos, 1864, vol. 1: $301 \mathrm{ff}$.

13 Ordenanzas de buen gobierno, 20.03.1524, Documentos cortesianos, 1993, vol. 1: 279.

14 GiBson, 1964: 78. See also Carta de Don Juan de Zumárraga al emperador, 1533, Documentos inéditos del siglo XVI, 1975: 20, 29 and 34. 
ple, they were solely interested in finding a way to get direct control over them and to do with «their» Indians as they pleased. They saw them mainly as a human resource.

As far as their own collective identity is concerned they felt more «Spanish» than before the conquest. The reasons were on the one hand the «transitional rite» of crossing the Atlantic ocean which meant an exceptional experience to all the individuals who suffered and survived it and made them see things differently ${ }^{15}$ (Or, to say it in Pedro Martír's words: Men who departed like peaceful lambs after their landing in the New World became killing wolfs $\left.{ }^{16}\right)$. On the other hand the reason was the geographical separation that with increasing temporal separation caused the danger of an «uprooting» of identity. The counter-reaction was that the conquerors emphasised their being Spanish in a part of the world where nobody else was Spanish ${ }^{17}$ and often demanded being regarded as hidalgos. In some cases they even changed their names ${ }^{18}$. But later, by returning to Spain for claiming their encomiendas they should also learn that by crossing the Atlantic in the opposite direction these new identities often melted like snow in the sun ${ }^{19}$.

An interesting special case is Hernán Cortés himself. During and after the conquest he felt like a prince in two cultural complexes. After the peaceful usurpation of Motecuhzoma's position 1519 had failed, Cortés tried to reach his aim by force. He took his place by right of conquest and made pregnant several daughters of Motecuhzoma, possibly to emphasize his claim to ruling. And although the majority of the conquerors spoke against it with good reason, he decided to build the capital of New Spain on the ruins of Tenochtitlán. Like in former times it should again be «queen» of the surrounding provinces. And what is more: his own palace was constructed on the same place as Motecuhzoma's, so that here he in an architectonic act claimed Motecuhzoma's position. Moreover, the early Mexican historiography invented a downright Cortés-myth. It pictured Cortés as an almost divine teule and constructed the legend of Quetzalcóatl-Cortés. In this manner he not only was exalted in the supernatural but also - as far as perception is concerned - Indianized. On this Indianized perception Cortés in person already had worked during the conquest. He knew all tricks of psychological warfare and was able to stress or

15 Pagden, 1996: 12.

16 MARTYR, Dek. VII, Buch IV, Kap. XVIII, 1973, vol. 2: 197.

17 Liss, 1996: 47.

18 Carta de Don Luis de Velasco, el primero, a Felipe II, 07.02.1554, Documentos inéditos del siglo XVI, 1975: 206.

19 PAgden, 1996: 13. 
soften moments of cultural shock. Any stressing (f. e. by demonstrating the force of European arms) favoured his supernatural exaltation, any softening (f. e. by speaking through the tongue of his young female translator Malinche) his Indianized perception. Sometimes, he even put some precious exotic feathers in his hat ${ }^{20}$.

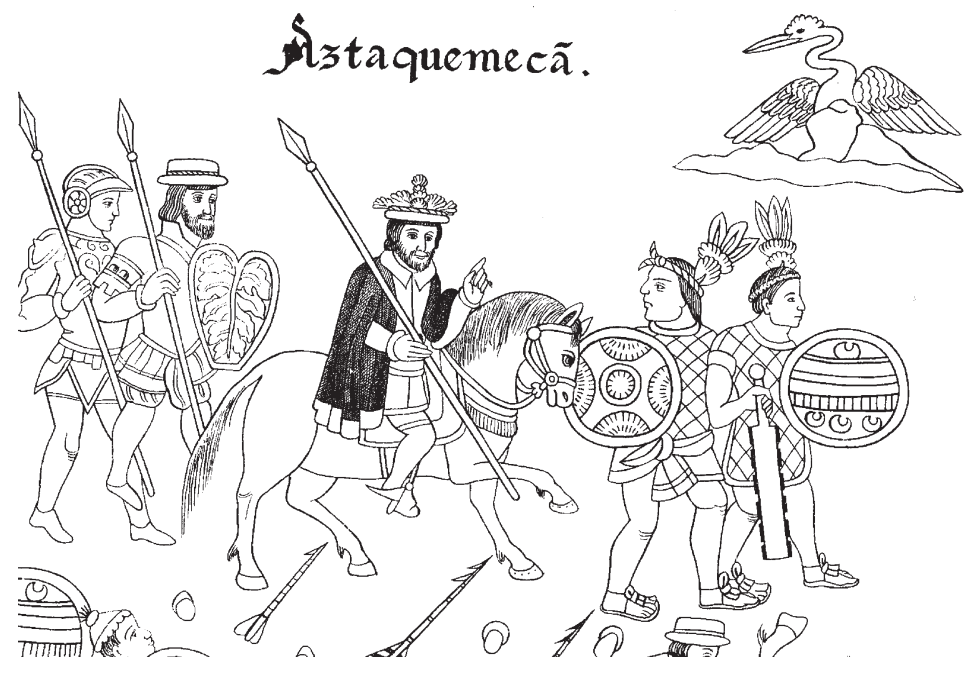

Picture 1: Lienzo de Tlaxcala, lam. 24.

This pattern of perception and his usurpation of Motecuhzoma's role established the exceptional veneration of Cortés by many Mexican Indians. Gerónimo López in a letter assured: «They [sc. the Indians] did not only obey Cortés in what he ordered, but [already] in what he thought, if they managed to get it into knowledge — and this with so much devotion, fire, reverence and promptness that it amazed $»^{21}$.

Though Cortés wrote a lot, everything was addressed to Spanish readers first and foremost to the Spanish king. Of course, here he avoided making the impression that at the conquest of Mexico he had aimed a charisma that re-

20 Lienzo de Tlaxcala, 1979: lam. 24. In SAhagún, Buch XII, Kap. XV, 1927: 488 it says, that by meeting Motecuhzoma in Tenochtitlán the Spanish crossbowmen had feathers of the Mexican Resplendent Quetzal in their helmets. (In the Spanish version of the Historia general this is not mentioned.)

21 Carta de Gerónimo López al Emperador sobre [...] la influencia de Cortés, México, 25.02.1545, Documentos cortesianos, 1992, vol. 4: 275. 
sulted in an authority that no other royal official ever could obtain. And naturally he kept secret any signs for his acceptance as Indian ruler and never calls himself a tlatoani. In any other case he would have promoted the rumours of his infidelity. Thus in 1529 he depicted himself at the emperor's court as a ruler over Indians, but not as an Indianized ruler: his retinue consisted of conquistadores, noble Indians from Tenochtitlán, Tlaxcala and Cempoala, f. e. a son of Motecuhzoma and another of Maxicatzin (one of the Tlaxcaltec tlatoque), Indian acrobats, musicians and more. Eye-witness of Cortés' appearance was the German Christoph Weiditz who made several pictures. He painted Cortés as a Spanish nobleman behind his coat of arms, with its three crowns for the defeated Mexican rulers and the city of Tenochtitlán and its frame of seven more heads of defeated tlatoque, linked by a chain. But Cortés showed more than booty and barbarians like a Roman triumphator. He did not represent any but his very own province, and he was proud of its wealth and high culture - and identified himself already with it. The city in his coat of arms should bloom again and the three crowns with new brightness become his own.

Cortés became a dazzling character with an awareness of having a special aura being a ruler in two different cultural complexes. In either cultural complex he emphasized the other one to evoke the exotic and astonishment. On this based his authority.

Following this scheme the appearance of Cortés at his campaign to Honduras was not less exotic than the one at the emperor's court in Spain. This time he presented himself in the tropical rainforest as a Renaissance prince: instead of suitable equipment for a to the exhausting project, he surrounded himself with a retinue existing of several officers, two clergymen, a major-domo, a barber, a confectioner, a cellarer, a financial administrator, a personal steward, a doctor, several page-boys, two falconers for hunting, musicians, acrobats, a juggler who also gave puppet shows, and a stableman ${ }^{22}$.

The king and his council saw Cortés' position and behaviour with distrust. He preferred to rule over New Spain in a more direct manner. Although the Crown implemented a regulation calling the Indians to coexist with the Spanierds in the name of Hispanization, the Spanierds neglected it. Because of this in the Junta Magna (1568) the separation and establishment of república de indios and república de españoles was enacted. The regulations were directed against the influence of the pope and the Spaniards living in the New World. Under the pretext of conversion, King Philip II pressed ahead with the

22 Díaz del Castillo, cap. CLXXIV, 2005, 634. 
reorganization of the Church in Las Indias and he saw to it that his authority was well respected ${ }^{23}$. With this the period of local Hispanization experiments was mainly over and now the Crown was better informed than at the beginning of the $16^{\text {th }}$ century. It had managed to gain experience and facts, had successfully deprived the encomenderos of their power and had reached the peak of its power with the help of the resources from Las Indias and New Spain. The experience of the conquest and the dealing with it sharpened the collective Spanish identity. Taken together, both contributed largely to the later Spanish nation state.

\subsection{Transformation of collective identities at Mexica and Tlaxcaltecs}

The Mexica and Tlaxcaltecs had been highly developed and complex groups with distinct and firm identities. As the physical diseases of the Old World fell on «virgin soil» and ravaged the native population, the demographic disaster they caused, aggravated by other determinants, probably had the strongest influence on the undermining of Nahua identities: The cultural, social and political elites died in such rapidity and number that they could not be replaced, and the socio-political, lateral organization of the traditional altépetl (city-states) as well as the one of their cultural memory was severely disturbed. Badly regulated successions and inheritances caused confusion and promoted the ruin of Indian dynasties as well as crime and general insecurity. They prevented the tradition of manifold special knowledge of the so-called «story tellers» and weakened the power of resistance against intentions of Hispanization and Christian mission on the part of the new masters. Without the disastrous effects of the epidemics the Nahuas would have remained a more self-confident and proud people. This is because the cultural achievements on which collective identity are founded, are only possibly based on economic surplus which on the other hand, presupposes social stability and unequivocal administration of the law.

As often in case of a violent conquest, especially the weakened nobility and upper classes of the conquered co-operated for the sake of the own advantage with the victors. To some pilli (Nahua nobleman), tecuhtli (Nahua peer) and tlatoani («great speaker», ruler) it seemed more desirable to win recognition within Spanish society and to preserve their prosperity than to stand up for the traditions of the own group and the right of being different. Cortés had demonstrated, by hanging Xicoténcatl the younger, Cuauhtémoc and many

23 Ramos, XXIII (Cologne, 1986): 1-61. 
others that there would be no place for dissenting Indian leaders in New Spain. As far as the Spaniards are concerned, intermediation of tlatoque (pl. of tlatoani) who had to subject to the Spanish Crown and convert to Christian religion was permitted and even desired. Symptomatic was their habit to associate with Spaniards in Spanish clothes and in Indian clothes with their own subjects.

In her study, The slippery earth about the Nahuas under Castilian domination, Luise Burkhart comes to the conclusion that although the Nahua-world after the conquest became more «slippery» for those who kept the balance it still remained a Nahua-world ${ }^{24}$. And indeed the occasionally alleged total collapse of the Nahua-world after contact with the Spaniards has to be put into context. The conquest of Tenochtitlán-Tlatelolco had been a war between Nahuas, that Cortés with luck and adroitness knew to lead. Motecuhzoma who overbearingly had felt obliged to inform Cortés that he - Motecuhzoma - was not a god had misjudged the character of the strangers and probably underestimated the danger that was caused by them. With the total military defeat of the Mexica that made them suffer the devastation of the Tlaxcaltecs, other hostile Nahua armies, the Spanish conquerors, and finally of the Christian missionaries, their traditional religion which was closely linked to their political organization literally «went to hell». But in 1519 and 1520 this turn of events was not predictable. For this reason it is not correct to speak of a «cultural shock» in case of the Mexica and even less in case of the Tlaxcaltecs. The Castilians had not been divine beings for them, the way it is often suggested by mentioning the teule-name and the myth of Quetzalcóatl. Each altépetl tried more or less successfully to make use of the knowledge and capabilities of the strangers for their own purposes. Thus, the problem of transformation was not that the Nahuas did not accept Spanish-Christian elements which usefulness and fascination they recognized, but that they should in turn abandon some elements of their own essential identity. It is therefore more appropriate to speak of a traumatic loss. The Mexica suffered such a traumatic loss because of the destruction of their traditional, architectonically carefully formed und religiously deeply inspired way of life, whereas the Tlaxcaltecs experienced a similar loss some time later mainly because of the demographic disaster caused by the epidemics.

First modest tendencies of Hispanization of Mexica and Tlaxcaltecs like $\mathrm{f}$. e. the knowledge of Spanish trade of war and some first vocabularies are as-

24 BurkHART, 1989: 193. 
certainable as early as 1519-1521 during the conquest. Christianisation, on the other hand, from the beginning was an important factor in the conqueror's way of thinking and acting because it represented the only undisputed legitimation of Spanish conquest. It was for that reason considered a bellum iustum. Cortés, inspired by a deep religious piety determined especially by Deuteronomy, personally preached Christian belief several times to the Indians during the conquest $^{25}$. Viewed from the perspective of that time, Christian belief cohered closely with «man-building» and civilization respectively policia ${ }^{26}$. In this connection the baptisms of some individuals that were effected at least in Tlaxcala during the war were of special importance. The ignoring of an existing and assignment of a new name is a ritual that gives a clear idea of the transformation of identity. The name-assigner makes «callable» the nametaker with a name that the name-assigner appoints — and with this he makes him controllable and governable. The powerful in this sense puts his stamp, an assigned and standardized identity, on the powerless. In Christian understanding baptism is a ritual of purification that symbolizes the integration within the parish, the assignment of a Christian identity and the washing off of the diabolical.

The Christian mission that the conquerors began was continued systematically by the Order of St. Francis, the Dominican friars and the Augustinian hermits. Although the Franciscan friars can be considered as the most important civilizers of New Spain, they refused to be mediators of a Hispanization in a strict sense. Fray Geronimo de Mendieta OFM expressed the most extreme point of view: «The Hispanization and the Christianisation of the natives were mutually exclusive. Not only was Hispanization destroying their Christianity, but also they were only capable of becoming grotesque mimics of the Europeans ${ }^{27}$. He was of the opinion that contact with Spaniards, who often gave a very bad example of Christian life and behaviour, made Indians downright diabolical.

In this context it should be mentioned that not all Franciscan missionaries in New Spain had been Spaniards. There were also friars from the Netherlands ${ }^{28}$,

25 TAPIA, 1939: 70.

26 About the term policía see: PrIEN, 1985: 204-208.

27 PHELAN, 1956: 85.

28 Johan van den Auwera (in Spanish Juan de Aora or de Ayora; Torquemada, lib. XX, cap. XVIII, 1975, vol. 3: 426), Johan Dekkers (in Spanish Juan de Tecto or de Toict or de Teta; ibid.: 424-426), the famous Pieter van Gent (in Spanish Pedro de Gante, Pedro de Moor or Muer or van den Moere or Mura; ibid., cap. XX: 429) and Fray Nicolás de Witte (Liss, 1996: 165f.). 
France $^{29}$ and other countries ${ }^{30}$. Abad Pérez writes in respect of the famous first three Flemish missionaries Gent, Auwera, and Dekkers: «Their Germanic roots determined very soon the outlines of their apostolic work $»^{31}$. This set the course for their successors, because they were the pioneers in all respects of Christianisation in New Spain. They began conversion with the children (they are mouldable and will pass on their Christian belief to their own children), they destroyed heathen religious objects and temples, and they founded schools. Also they set the course in their pupils' learning objectives, in the formation of religious Indian brotherhoods or with the understanding that Christian mission only can be successful in Nahuatl.

Thus, the Franciscans agreed about not to extend a «Spanish» Church in Mexico but to create a pure and new one without the corruption of the Old World. Nevertheless they saw themselves as teachers of civilization, because «fruitless are [...] humans, who live without the knowledge of God» ${ }^{32}$ and «what could be expected [from a land] that lacked the grounding of [Christian] faith?» ${ }^{33}$. In 1523 fray Pieter van Gent founded — because Tenochtitlán still was totally destroyed - in Texcoco the first school in the palace of Nezahualpilli with almost 1000 sons of noble Mexican and Texcocan families. He taught them the Latin alphabet, Latin songs, to make music with European instruments, to draw and paint in European way, he taught them new agricultural technics as well as European crafts like stone-cutter, carpenter, tailor, shoemaker, smith, bell founder ${ }^{34}$, and of course, he instructed them in Christian religion. Following this model he established a school in Tenochtitlán next to the chapel San José de Belén de los Naturales ${ }^{35}$. Here daily 500-600 boys were educated ${ }^{36}$. The teaching of the European crafts should serve mainly to attract and provide for the Christian Indian pupils later a socially higher position by their useful specialized knowledge. Regarding his curriculum Fray Pieter could not only refer to personal experiences from his own education in the Netherlands, but also by those of his order with similar schools during the Caribbean stage.

29 Fray Arnaldo de Bassaico was born in France (TorquemadA, lib. XV, cap. XLIII, 1975, vol. 3: 113). Other «French» Franciscans were Jacobo de Testera (ibid., lib. XX, cap. XLVII: 488), Maturino Gilberti (ibid., cap. LV: 509), Juan Fucher (ibid., cap. LVI: 510) and Antonio de Huere (ibid.: 511).

30 Fray Jacobo Daciano f. e. came from Denmark (ibid., cap. LIII: 502).

31 ABAD PÉREZ, 1992: 34.

32 SAhagún, lib. I, ap., 2000, vol. 1: 113.

33 Herrera, dec. V, lib. V, cap. XI, 1952, vol. 10: 399.

34 PAZOS, 1973.

35 Torquemada, lib. XX, cap. XIX, 1975, vol. 3: 428; Gómez Canedo, 1982: 56.

36 Lockart and Otte, 1976: 213. See the letter to Charles V, 1532, by Pedro de Gante. 
First these efforts seemed to be very successful. But the fundamental mistake in this attempt was to regard the Indians as an unknown quantity, a dark horse: respectively mouldable «children». The friars knew their language, but were not familiar with the collective identity of the Mexica and Tlaxcaltecs and also thought for the time being that there was no need to be so. The later understanding that the Nahuas had not totally lost their traditional identity completely made the missionaries look upon them as «impenitent» children. - «Impenitent» pagans on the other hand according to the Franciscan religious doctrine of $16^{\text {th }}$ century conjure up the wrath of God and punishment. The further discernment that a successful mission would be impossible without an extensive understanding of the identity of the other led to partial attempts to reconstruct the traditional Indian special knowledge by singular friars like Andrés de Olmos, Toribio de Benavente, or Bernardino de Sahagún. But this also did not have the effect that the monks in general felt much sympathy for Nahua culture later on.

Because of the fact that the Nahuas were a strongly lateral organized people, the death of the «story tellers» - especially in the case of the Mexica had made their cultural memory so to speak headless. After the arrival of the Franciscan missionaries they controlled its construction. Thereby it was fundamentally given a new interpretation: The gods of the old religion became devils of the new one, with the result that the history of salvation which seemed an incompatible part of the traditional history of the Nahuas was accomodated to it, particularly by using Flavius Josephus' Jewish war (omens of the near conquest, and sling stone against Motecuhzoma as the stone of the obstinate pagans against the one who recognizes God and understands the uselessness of resistance) and The Revelation of St. John (conquerors as lash of God for the sinful pagans and melancholic Motecuhzoma who wants to hide).

Hispanization and Christianisation were not successfully implemented in all parts of Mexico and among all social classes. Many Mexica and even more Tlaxcaltecs did not have much contact with missionaries and Castilians. Only few especially educated knew how to speak and write Spanish so that even elementary aspects of policia and Christendom from most of the macehualtin (members of the lower social Nahua classes) especially in rural and rough regions of Tlaxcala could have been adopted only in a rudimentary manner. The reason was not that they had theoretically not been capable to comprehend and understand Spanish concepts, but that there were only very few Spanish «teachers» and that the Nahuas like any other group as a matter of principle tried to persevere their traditional way of life and culture. Above all in agriculture, the base of existence, many pagan rites and ideas survived. The result of insufficient substitutes for prohibited traditional elements was a general feel- 
ing of loss of identity and the uncertainty that the Nahuas called nepantla ${ }^{37}$. Alonso de Zorita knew this from experience of many years. The main objective of his Relación de los señores de la Nueva España is, to accuse the partly disastrous results of reckless measures of Hispanization and oppressive demands of tribute:

The old monks in that country say that it began after the native came under the rule of the Spaniards and that [therefore] was lost the good government which they used to have, that there was no more [social] order and policia and legal order as well as its execution were lost, which they had preserved. The processes and divorces increased and everything turns out in disorder.

I asked a pilli (nobleman) in México about the reason for it, that the Indians today devote to so many processes and that they continue to do so as if they were addicted to it. He said: "Because neither you understand us, nor we understand you, nor we do know what you want. You took our good order and government away. And we do not understand the one [i. e. the order], that you forced upon us, and so everything is in confusion and without order" 38 .

This problem of nepantlism was frequently solved by veiling of forbidden Nahua concepts or elements with a Spanish or Christian surface ${ }^{39}$. The Franciscans construed this as an unacceptable syncretism that falsified their idea of a primitive and pure Church that they wanted to establish in New Spain.

Picture 2: Stoup with the Tlaxcalan god Camaxtli as column. San José de Tlaxcala (Photo FH).

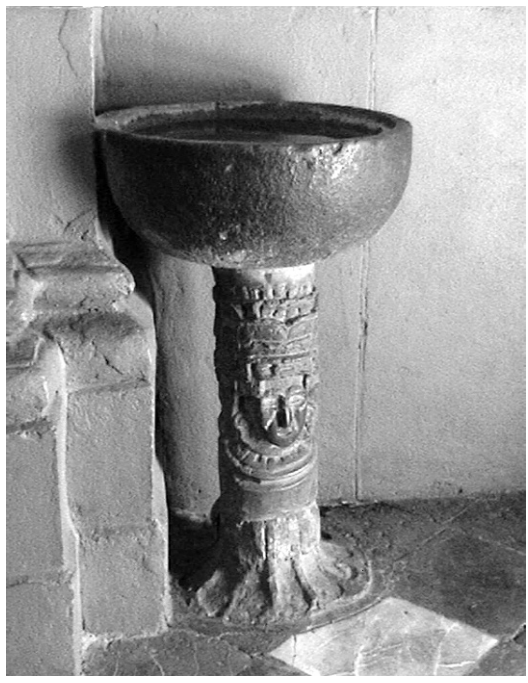

37 LeÒn-Portilla, XI (México, 1974): 32f.; Nepantla means «being in the middle» - that is being fallen between two stools.

38 ZORITA, cap. IX, § 98f., 1992: 87; ibid., § 99f.: 88.

39 BURKHART, 1989: 188. 
Properly speaking syncretism is nothing unusual in the history of Christianity: There had been inter alia a Hellenization, a Romanization, and a Germanization. In these cases one can speak more or less of an inculturation of Christianity. But in the case of the Mexica and Tlaxcaltecs the expectations of the missionaries were much higher because they had - in contrast to their predecessors in the Hellenistic states, in Rome or in respect of the Germanic tribes - the military force on their side. Thus they could threaten the Nahuas: «Now, if you do not want to obey [...] you will be in great danger. And God, who started with your annihilation, will bring it to an end that you will perish totally» ${ }^{40}$.

The high demands of the Augustinian hermits, the Dominican friars and the Franciscan monks were - no wonder from today's point of view — disappointed by the Nahuas. For this reason they were continually regarded as «children» during the $16^{\text {th }}$ century, instead of becoming «brothers» (friars) of equal rights. But without a real indigenous clergy, Indian monks, priests and even bishops, an inculturation of Christianity that deserves this term was impossible.

This should have a long-term influence on the juridical and political position of the Nahuas in New Spain. During the investigated period (1519-1568) the Crown, due to lack of money felt repeatedly compelled to permit forced labour of the Indians. The abolishment of this treatment did not finally mean the acceptance of the Nahuas as equal to Spaniards. Although they shall not be forced to work, they were regarded as weak in faith and stamped to be weak and protection-needy beings in any respect allowing their social und political equality to become impossible.

But again from the beginning. If the Mexica had really thought that the Spaniards would depart and that they could win back their former importance and power, they had to dismiss these hopes in 1525 along with the death of Cuauhtémoc at the latest. Since then their only «privilege» was to be regarded as being Hispanized best because they lived in the immediate vicinity of the Spaniards in the capital. They were obliged to lend them a hand on a daily basis. Although they lost thousands of people their number still was considerable so that the Spaniards always regarded them as a potential danger. For this reason the Spanish government of New Spain denied equally entitled high administrative offices to the Mexica - although this was precisely what Charles V and the Council of the Indies had in mind:

It seems to Us now because the Indians who live in that province start to understand our way of life, government, policia, and affairs of state that it should be con-

40 Sahagún, Colloquios y doctrina christiana, Kap. VIII, 1949: 109, B 1140-1148. 
venient, that there would be persons of them who enter together with the Spanish regidores $[\ldots]$ in the government and would have the right to vote. Likewise [We wish] that in each settlement there should be one alguacil of them, because except the mentioned advantages it seems that in this way they develop more affection to the Spaniards and [... ] they gain faster knowledge of our Holy Catholic Faith. And thus We give instruction to send to you ten certificates of appointment in blank for regidores and eight for alguaciles. After you informed yourself about the conditions of the country and [...] about the best qualified persons in the city of México and it seems to you that they demonstrate more ability and affection to the policy, you appoint two of them to regidores and a further to alguacil. You speak with them in Our name give them to understand Our instructions and register their names in the documents, which you hand over to them and let them enter into the town council. You are to speak with the [Spanish] alcaldes and recidores that they treat them very well and politely and say to them, that otherwise We are served very badly. Exactly like this is to proceed in other cities which you consider suitable ${ }^{41}$.

The first audiencia feared loss of authority and delayed the king with the argument, that it would not be so easy to accomplish and that the case had still to be examined more closely. They were afraid also, that the Mexica would learn unpleasant things within the debates about the disagreement of the Spaniards and their bad political manners ${ }^{42}$. The Spanish cabildo of México, the notorious enemy of the audiencia at that time, supported the attitude of the Crown and deplored in a memorandum the administrative division of the city in the Spanish and the Mexican Tenochtitlán and in Santiago de Tlatelolco, which did not let become a unit of the city. It therefore 1561 suggested a united cabildo like the one of Granada with 24 regidores, in which should sit 18 Spaniards as well as three honourable Mexica from Tenochtitlán-México and from Tlatelolco - «because this city is wishing, that the natives of this country and the Spaniards are one and the same and that they are respected and treated as sons of the same Spanish nation $»^{43}$. However, the striking disproportion of total population and representation in the council proves that this argumentation was pure rhetoric: the Spanish cabildo just intended to extend and legitimize its influence on the Tenochca (and even on the Tlatelolca) under the pretext of «equal» rights. Actually, such experiments of a mixed Spanish-Indian cabildo only in Puebla de los Ángeles had been accomplished (1561).

41 Capitulo de la carta que S.M. la emperatriz escribió á la Audiencia de Nueva España, 12.07.1530, Colección de documentos inéditos, seg. serie, 1897, vol. 10: 53f.

42 Ruiz Medrano 1991: 52; Carta del presidente R. de Fuenleal a la emperatriz, 15.05.1533?, Epistolario de N.E., 1942, vol. 15: 164.

43 7. $^{\circ}$ libro de cabildo, 09.01.1562, s.a.: 11; ibid. 29.04.1562: 38 and Relación y memoria, Libro del cabildo, s.a.: 492f. 
Thus, the equalization of the Nahua and the Spaniards failed in ecclesiastical as well as in political respect. The king disappointedly complains: «The talent and [mental] ability of the Indians, which are not greater than at small boys, are already well-known: in the majority they are scared and subservient just as they are; one is not to wait for the day that they change on their part, because they have neither a mouth for speaking nor for bleating, although the neck is cut off to them as with lambs» ${ }^{44}$.

Because of this for the Indians the offices protector de indios and corregidor were created, in order to guide and teach them. Regardless whether these offices originally were meant benevolent or not one has to consider the fact that in each case a Spaniard protected the Indians, represented a certain tutelage which was not appropriate to promote equal rights of the Indians at all. A free man in medieval understanding was someone who could claim and defend his rights on his own. Also it is delicate that Juan de Zumárraga OFM, since 1528 the first protector de indios in New Spain ${ }^{45}$ and since 1535 officially inquisitor ${ }^{46}$ by religious conviction from the outset pursued the destruction of the religious and cultural memory of the Nahuas ${ }^{47}$, what in his and in the understanding of his Castilian contemporaries was not cogently a contradiction.

This meant that the «liberty» of the Indian implied the obligation of self-Hispanization. Since they did not do this voluntarily, they were considered as «weak», i. e. as not consciously and strongly enough to be «free» in accordance with Spanish policia. This required on the one hand protection, on the other hand also an external guidance for Hispanization.

In contrast to his first instructions, Charles $\mathrm{V}$ changed his mind soon and ordered to concentrate the rural population in settlements for this purpose. $\mathrm{He}$ and Philip II instructed into reales cédulas from 1538, 1549, 1550 and 1560 to unite the Indians where this was necessary, while the ecclesiastical junta of 1546 and the councils of 1555 and 1565 aimed at the same goal ${ }^{48}$. An important other request of the Crown had always been the teaching of the Spanish language among the Indians. It never gave up this demand, but only accepted if necessary the practical impossibility to force the few clergymen of New Spain against their will to this large-scale project ${ }^{49}$. The respective language as

44 Torquemada, lib. XVII, cap. XIX, 1975, vol. 3: 258. Unfortunately T. does not give information about time and date of this passage.

45 García ICAZBalceta, 1947, vol. 1: 49.

46 Título de inquisidor, 27.06.1535, ibid., 1947, vol. 3: 71ff.

47 Ibid., 1947, vol. 2: 87-117.

48 Borges Morán, 1987: 115.

49 SARABiA Viejo, 1978: 148. 
a sign of the rationality was considered as an indication of the degree on policia, which was to be assigned to a group. From the Spanish point of view the Spanish could meet these requirements (apart from Latin) best, and the Crown hoped that central, untranslatable concepts of Spanish «civilization» and the Christian faith would be better understood and accepted if the Indians first learned to speak und understand Spanish. In the consequence it would by imparting the Spanish way of thinking - develop from an instrument to an independent agent of the Hispanization. But there were only a few monks, who also did not want to define themselves just as Spanish teachers.

In addition, the Crown demanded not just to teach Spanish to Indians. Charles V in 1536 on the contrary, found it appropriate that Spanish children of Mexico in the schools should learn Nahuatl by way of trial. This would prepare them better for their later occupations and positions as priests or high officials in New Spain ${ }^{50}$. Fray Rodrigo de la Cruz OFM suggested to the Crown in 1550 letting all Indians learn Nahuatl. Viceroy Velasco (the older) placed the same request eight years later, not least regarding the abuse which some Indian interpreters, the so called nahuatlatos, made with their knowledge ${ }^{51}$. The Nahuatl under Spanish rule had a clearly larger expansion than until $1519^{52}$, which seemed to some Spaniards almost diabolical ${ }^{53}$.

For the time being the Mexica and Tlaxcaltecs had different ideas with regard to politics. While the Mexica were under direct Spanish control from the beginning, the Tlaxcaltecs tried to avoid this by insisting on their privileges of self-government, of residence prohibition for Castilians and liberation from tribute. The Tlaxcaltecs theoretically had a privileged position in New Spain, «because of their participation in the conquest of this country as well as because of the confidence, which one finds with them to get each support and assistance, therefore it makes sense that they are treated somewhat better than the others [other Indian peoples] ${ }^{54}$ — as Viceroy Mendoza explained. But all these privileges mainly existed on paper and could only be enforced in each case for short times and by costly diplomatic missions from Tlaxcala to Spain.

What is noteworthy here is the Tlaxcaltecs' will of self-Hispanization during the $16^{\text {th }}$ century. They assured in this respect: «The city of Tlaxcala is not

50 Lo que D. A. de Mendoza [...] ha de hacer en la dicha tierra, por mandado de S.M., 1536, Colección de documentos inéditos, 1875, vol. 23: 456.

51 Letter of Fray Francisco de la Cruz to Charles V, 04.05.1550, RiCARD 1974: 50 and Sarabia Viejo 1978: 149. Also see Chimalpáhin, 2001, 409.

52 Sarabia Viejo 1978: 149.

53 Baudot, 1977: 94f. (Thomás López, 25.03.1551).

54 Carta de D. A. de Mendoza al emperador, 10.12.1537, Colección de documentos inéditos, 1865, vol. 2: 181 . 
built from pride, but for that Tlaxcala gets a good appearance» ${ }^{55}$, that means a «Spanish» appearance. This will to self-Hispanization and pride of Tlaxcala becomes particularly apparent in the acquisition of the big mechanical clock in 1549. The benefit of this acquisition was very questionable since the Spanish oidor Santillán had not required a clock in Tlaxcala by any means. Even if the Tlaxcaltec upper class should have been familiar with European time measurement, there would hardly have been a practical need of a mechanical clock in the town. It surely was a status symbol, whose value was very high, so rare was this technical equipment in New Spain. Probably at that time only in México-Tenochtitlán (on the older palace of Cortés) was there anything comparable. In order to justify the purchase, the cabildo argued, «that the clock is really needed in order to honour the emperor, thus Tlaxcala receives a good appearance ${ }^{56}$. Unfortunately it is unknown in which spatial context the clock was integrated later, but probably it decorated the cabildo building.

It's obvious, what the prestige and value such an expensive and rare, fine-mechanical object in early New Spain had. A clock by its regularly functioning symbolizes and states order: a key element of policia. In addition, it reminds the people to use time meaningfully. «Meaningful» for its part meant above all: to work and pray. The clock visually and acoustically directs ones attention to the place from which it hangs. Since a clock is not a self-explaining medium, the attention of the uninitiated is brought to astonishment and wonder. Thus can one assume that the purchase of the clock should honour only allegedly the emperor. Above all it creates a distance between the buyer: cabildo members and Hispanized upper class, and the other Tlaxcaltecs: the just partly Hispanized macehualtin, who had little experience with Spanish cultural concepts. In short, the clock created Spanish identity for the Tlaxcaltec upper class and separation in Hispanized and not Hispanized Tlaxcaltecs.

Tlaxcala's transformed collective memory was determined by the consciousness to belong to the conquerors of Tenochtitlán and thereby rank with the victors of the war. They stylized themselves as the most noble, indigenous pillar of Spanish and imperial power in New Spain and hoped in the beginning, to be able to take part in the process of exploitation and organization of the former territories controlled by the triple alliance Tenochtitlán - Texcoco - Tlacopán. However, Cortés and the local Spanish rulers did not intend to share with the Tlaxcaltecs but made similar demands on them as for the defeated Mexica.

55 Actas del cabildo de Tlaxcala, 12.04.1549, 1985: 260.

56 Ibid., 03.03.1550: $295 f$. 
This can not be the place to discuss all facets of Hispanization exhaustively, but let us only have a short look at the economic-technical aspect of policia: Las Casas and Zumárraga praised the mechanic abilities of the Nahuas: There was nothing that the Indians did not soon made just as good as the Spaniards ${ }^{57}$ and much of it they copied without special instruction ${ }^{58}$ But the Spanish master craftsmen looked upon them only as dangerous rivals and successfully discriminated Hispanized Mexica, hindering them to become apprentice or at least master. So the Nahua were excluded in many ways not only in their own former city, where they had to settle outside the Spanish traza.

Thus, after only a brief euphoria of Evangelization and Hispanization in the middle of the $16^{\text {th }}$ century, disappointment followed on both sides. It has already been mentioned how epidemics played a major part in this. The shipwreck of the Colegio de Santa Cruz project can especially be linked to the epidemics and was a setback for efforts of Christianisation and Hispanization. Here the Franciscan friars under the auspices of the Spanish Crown, had intended to build up a young Nahua elite for higher ecclesiastical and secular ministries beyond the "culture of conquest». But the fact that an indigenous clergy was not created was generally misunderstood as the Nahuas' incapability to meet the requirements of Spanish morality and policia. Since that time, the Nahuas were considered to be unqualified for higher posts in Spanish government and administration of Las Indias.

The legal incapacitation of the Nahuas in autonomous development of their collective identity is particularly obvious by looking more closely at the transformation of their cultural memory. Two chapters of the book " $H i s p a-$ nisierung" in Neu-Spanien» about (1) postconquest historiography and (2) town-planning between 1521 and 1568 provide more detailed information on this matter.

The Franciscan friars also had distinctive influence in the writing of history. They were not only interested in burning the Indian heathen codices which handed down the version of history that Tlacaélel invented and brought about corresponding to his new political religion, and those which might have existed in Tlaxcala. The monks together with their Christianised and Latinised Indian pupils, linked precortesian history with the history of the conquest and integrated it into the Christian history of salvation. The latter for them was universally valid. To convince the Nahuas of the truth of

57 Las CASAs, Apologética, cap. LXIII, 1992, vol. 7: 596.

58 Otro parecer del sr. Zumárraga al Consejo de Indias, s.a., Garcìa ICAZBALCETA, 1947, vol. 3,145 . 
their historical construction in the context of Sahagún's works they wrote it in Nahuatl and as if it was «Indian». This was also the case when the Franciscans feignedly used to appear as «Indians among Indians». But always as the «fathers» they kept the Nahuas on a short leash as if they were their immature «children». Basically, the defeated were not allowed to construct their social reality and interpret their own history any longer. Only those who adapted the Franciscan perspective escaped violent discrimination. Accordingly, the Tlaxcaltecs in their Lienzo de Tlaxcala (at least in the version of the Ms. Glasgow) ${ }^{59}$ assured that Christian Saints fought by their side against the Mexica.

The preponderant silence of the Mexica and assistance of the Tlaxcaltecs in the indicated «culture of conquest» is also obvious in town-planning and architecture. The most outstanding political and religious sites of memory of the aforementioned tribes were architectonically given a new interpretation in a Spanish sense or demolished as far as possible. But whereas the Mexica had to invest a lot of energy into the construction and building of the Spanish Tenochtitlán-Mexico and only had few ambitions and possibilities for building their own projects outside the Spanish traza, the Tlaxcaltecs worked with much effort on their own new capital after the model of an «ideal» Spanish town. But the expected appreciation on the part of the Spaniards ultimately failed to show. The foundation and systematically preferential treatment of Puebla de los Ángeles did not serve in the least for putting a stop to the increasing importance of Tlaxcala. Puebla could hold Tlaxcala in check just like Cholula had done according to Motecuhzoma's plan in times before the conquest. The forced labour of the Tlaxcaltecs in Puebla, as well as the transfer of the episcopal see to the new Spanish city, and the demographic disaster sealed the fate of Tlaxcala. Instead of competing with Tenochtitlán-México it became more and more a provincial town of little importance. Because of political and economical reasons, the Spanish governors decided to grant only such privileges to Tlaxcala which could not endanger Spanish domination in any way. That is why a participation of Tlaxcala in the process of exploitation and formation of New Spain was out of the question.

All this leads to the conclusion that it is incorrect to see in some Nahuas, like the Tlaxcaltecs, winners and in others, like the Mexica, losers of the conquest. By 1568 they all became just «indios». A complete Hispanization should not really be achieved. Instead, the process of Hispanization moved only in the context of the «culture of conquest».

59 Muñoz Camargo, 1984: lam. 52. 
On the other hand, as a result of the increasing (biological as well as cultural) mestizosation the Spaniards who lived in New Spain had changed - especially the conquerors and their direct descendants. Also, the way Spain saw itself was effected by this change.

Transformation of (collective) identity is never a one-way street.

In this synthesis only some exemplary aspects of Hispanization could be mentioned ${ }^{60}$.

\section{BIBLIOGRAPHY}

7. ${ }^{\circ}$ libro de cabildo que començo desde jueves primero dia de henero de mill y quinientos y sesenta y dos años acava en 26 de octubre de 71 [México D.F., ca. 1889].

ABAD PÉREZ, Antolín, Los franciscanos en América, Madrid, Mapfre, 1992.

Actas del cabildo de Tlaxcala, 1547-1567, Eustaquio Celestino Solís, Armando Valencia R. and Constantino Medina Lima (ed.), México D.F., AGN, 1985.

BAUDOT, George, Utopie et histoire au Méxique. Les premiers chroniqueurs de la civilisation mexicaine (1520-1569), Toulouse, privat, 1977.

Borges Morán, Pedro, Misión y civilización en América, Madrid, Alhambra, 1987.

BURKHART, Louise M., The slippery earth. Nahua-Christian moral dialogue in sixteenth-century Mexico, Tucson, University of Arizona Press, 1989.

Chimalpáhin, Domingo, Diario, Rafael Tena (ed.), México D.F., Conaculta, 2001.

Colección de documentos inéditos relativos al descubrimiento, conquista y organización de las antiguas posesiones españolas de América y Oceanía, sacados de los Archivos del Reino, y muy especialmente del de Indias, Luis Torres de Mendoza (ed.), 42 vols., Madrid, Quirós, 1864-1884.

Colección de documentos inéditos relativos al descubrimiento, conquista y organización de las antiguas posesiones españolas de ultramar, segunda serie, Real Academia de Historia (ed.), 26 vols., Madrid, Real Academia de la Historia, 1885-1932.

DíAZ del CASTILlo, Bernal, Historia verdadera de la conquista de la Nueva España (Manuscrito «Guatemala»), José Antonio Barbón Rodríguez (ed.), México D.F., El Colegio de México, 2005.

Documentos cortesianos. 1518-1548, José Luis Martínez (ed.), 4 vols., México D.F., UNAM, ${ }^{2} 1993$.

Documentos inéditos del siglo XVI para la historia de México, Mariano Cuevas (ed.), México D.F., Porrúa, ${ }^{2} 1975$.

60 The subject is exhaustively investigated at HiNZ, 2005. 
Epistolario de Nueva España, 1505-1818, Francisco Paso y Troncoso (ed.), 16 vols., México D.F., Robredo, 1939-1942.

Foster, George MacClelland, Culture and conquest: America's Spanish heritage, New York, Wenner-Gren Foundation for Anthropological Research, 1960.

García ICAZBAlceta, Joaquín, Don fray Juan de Zumárraga, primer obispo y arzobispo de México, 4 vols., México D.F., Porrúa [1881] 1947.

Gómez CANedo, Lino, La educación de los marginados durante la época colonial. Escuelas y colegios para indios y mestizos en la Nueva España, México D.F., Porrúa, 1982.

GrUZINSKI, Serge, La colonisation de l'imaginaire: Sociétés indigènes et occidentalisation dans le Mexique espagnol, XVIe-XVIII ${ }^{e}$ siècle, Paris, Gallimard, 1988.

Herrera y Tordesillas, Antonio de, Historia general de los hechos de los castellanos en las islas y tierra firme del mar océano, 17 vols., Madrid, Franco, 1934-1957.

Hinz, Felix, Hispanisierung in Neu-Spanien 1519-1568. Transformation kollektiver Identitäten von Mexica, Tlaxkalteken und Spaniern, Hamburg, Verlag Dr. Kovač, 2005.

Las Casas, Bartolomé de, Obras completas, 14 vols., Paulino Castaneda Delgado (ed.), Madrid, Alianza, 1988-1998.

Lienzo de Tlaxcala, Alfredo Chavero (ed.), México D.F., Cosmos, 1979.

LISS, Peggy K., Orígenes de la nacionalidad mexicana 1521-1556. La formación de una nueva sociedad, México, Fondo de Cultura Económica, 1996.

LEÒN-PorTILla, Miguel, «Testimonios nahuas sobre la conquista espiritual», Estudios de cultura nahuatl, XI (México D.F., 1974): 11-36.

Letters and people of the Spanish Indies, sixteenth century, James Lockhart and Enrique Otte (ed.), Cambridge, Cambridge Univ. Pr., 1976.

Libro del cabildo e ayuntamiento desta ynsine e muy leal ciudad de Tenuxtitan México desta Nueva España que comenzo a 1. ${ }^{\circ}$ dia del mes de diziembre de 1561 años [México D.F., ca. 1889].

LOCKHART, James, The Nahuas after the conquest. A social and cultural history of the Indians of Central Mexico, sixteenth through eighteenth centuries, Stanford Cal., Stanford Univ. Pr., 1992.

- and Отте, Enrique (eds.), Letters and People of the Spanish Indies, Sixteenth century, Cambridge, Cambridge University Press, 1976.

Martínez, José Luis, Hernán Cortés, México/Madrid/Buenos Aires, UNAM, ${ }^{2} 1992$.

Martìnez BARACS, Andrea Guadalupe, El gobierno indio de la Tlaxcala colonial 1521-1700 (Univ. Diss., México D.F., 1998) [in Casa Chata, México D.F.]. 
Martyr von AnghierA, Peter, Acht Dekaden über die Neue Welt, Hans Klingelhöfer (ed.), 2 vols., Darmstadt, Wissenschaftliche Buchgesellschaft, 1972-1973 [German translation of the Latin original].

Miralles Ostos, Juan, Hernán Cortés. Biografía, México, Tusquets, 2001.

Muñoz CAmargo, Diego, Descripción de la ciudad y provincia de Tlaxcala [1579-1585], René Acuña (ed.), México D.F., UNAM, 1984 [incl. Ms. Glasgow].

Pagden, Anthony, Das erfundene Amerika. Der Aufbruch des europäischen Denkens in die Neue Welt, München, Diederichs, 1996 [German translation of: European encounters with the New World].

PAzos, Manuel R., «Los misioneros franciscanos de Méjico y la enseñanza técnica que dieron a los indios», Archivo Ibero-Americana, 130-131 (1973): 149-190.

PHELAN, John Leddy, The millennial kingdom of the Franciscans in the New World. A study of the writings of Gerónimo de Mendieta (1525-1604), Berkeley, Univ. of California Press, 1956.

PrIEN, Hans-Jürgen, La historia del christianismo en América Latina, Salamanca, Sígueme, 1985.

RAmos, Demetrio, «La crisis indiana y la Junta Magna de 1568», Jahrbuch für Geschichte von Staat, Wirtschaft und Gesellschaft Lateinamerikas, 23 (Cologne, 1986): 1-61.

RICARD, Robert, The spriritual conquest of Mexico, an essay on the apostolate and the evangelizing methods of the mendicant orders in New Spain, 1523-1572, Berkeley, Univ. of California Pr. [1933] 1974.

Ruiz Medrano, Ethelia, Gobierno y sociedad en Nueva España. Segunda Audiencia y Antonio de Mendoza, Zamora Mich., El Colegio de Michoacán, 1991.

SAHAgún, Bernardino de, Historia general de las cosas de Nueva España (versión íntegra del texto castellano del manuscrito conocido como Códice florentino), Alfredo López Austin and Josefina García Quintana, 3 vols., México D.F., Conaculta, 2000 [Spanish version].

- Einige Kapitel aus dem Geschichtswerk des Fray Bernardino de Sahagun aus dem Aztekischen übersetzt von Eduard Seler, Cæcilie Seler-Sachs, Walter Lehmann and Walter Krickeberg (ed.), Stuttgart, Strecker und Schröder, 1927 [Nahuatl version of the Historia general and its German translation].

- Colloquios y doctrina christiana - Sterbende Götter und christliche Heilsbotschaft. Wechselreden indianischer Vornehmer und spanischer Glaubensapostel in Mexiko 1524. "Colloquios y doctrina christiana» des Fray Bernardino de Sahagún aus dem Jahre 1564, Walter Lehmann and Gerdt Kutscher (ed.). Stuttgart, Kohlhammer, 1949 [Nahuatl version and German translation].

Sarabia Viejo, María Justina, Don Luis de Velasco. Virrey de Nueva España 1550-1564, Sevilla, Escuela de Estudios Hispano-Americanos, CSIC, 1978. 
TAPIA, Andrés de, «Relación de algunas cosas de las que acaecieron al Muy Ilustre Señor Don Hernando Cortés», Agustín Yáñez (ed.), Crónicas de la conquista, México, UNAM, 1939: 41-96.

Torquemada, Juan de, Monarquía indiana, Miguel León-Portilla (ed.), 3 vols., México D.F., Porrúa, 1969 and 1975 [Facs. of the second edition, Madrid 1723].

Zorita, Alonso de, Relación de los señores de la Nueva España, Germán Vázquez (ed.), Madrid, Historia 16, 1992.

Fecha de recepción: 24-9-2006

Fecha de aceptación: 23-7-2007

\section{HISPANIZACIÓN EN LA NUEVA ESPAÑA 1519-1568. TRANSFORMACIÓN DE IDENTIDADES COLECTIVAS EN LOS MEXICAS, TLAXCALTECAS Y ESPAÑOLES}

Este artículo examina los métodos aplicados, y los resultados surgidos del cambio cultural que ocurrieron con la conquista de México y los comienzos de la Nueva España. Es el intento de sistematizar los mecanismos de la evangelización y la hispanización, comprendida como un proceso recíproco de transformación de las identidades colectivas. El hecho de que no se creara un clero indígena, en general fue malinterpretado como el resultado de una poca capacidad de los nahuas de adaptarse a la civilización («policía») y a la moral española. Esto tuvo efectos tanto en las esferas políticas como arquitectónicas y historiográficas. Pero también los españoles y los demás europeos tuvieron que cuestionar su autognosis después del contacto con la cultura nauahtl. Ser español antes y después de la conquista, no fue lo mismo, como tampoco lo fue ser español en España y en las Indias.

Palabras clave: Cambio cultural, Nueva España, evangelización, hispanización. 